DOI: https://doi.org/10.4796o/2303-7431.24.2020.6o

UDK: 316.774

Izvorni znanstveni članak

Primljen 14. XI. 2020.

Prihvaćen 20. IV. 2021.

IVAna Primorac Bilaver

Sveučilište u Mostaru, Filozofski fakultet

ivana.primoracbilaver@ff.sum.ba

\title{
ODGOVORNOST I POVJERENJE U MEDIJSKOME KOMUNICIRANJU KRIZE
}

\section{Sažetak}

Svjetska zdravstvena organizacija 2020. godine proglasila je globalnu pandemiju, a time i najveću krizu posljednjih desetljeća. Kriza je, prije svega, opasnost, rizik, a tek potom prilika. Svaka je kriza trajni izazov čovjekovoj inteligenciji i egzistenciji, pa je tako i antropološka konstanta. Pitanje o krizi pitanje je i o čovjeku. Ona je, također, medijska konstanta i izvor trajnoga zanimanja medija. Ne postoji jedinstveno gledište oko definiranja krize. Iz definicija krize izdvajamo: neplaniranost, neželjenost, traženje odgovara i ranjivost. Dva potonja pojma sadrže i priliku za uspješno medijsko komuniciranje krize. Postavlja se pitanje: „Mogu li mediji kroz koncepte odgovornosti i povjerenja mijenjati krizu i neutralizirati njezine moguće štetne učinke?" S etičkoga stajališta kriza nas poziva da intenzivnije razmišljamo o čovjeku kojega nam mediji približavaju u vrijeme socijalne distanciranosti.

Ključne riječi: kriza; čovjek; mediji; odgovornost; povjerenje

\section{Uvod}

Krize su karakterizirale mnoga razdoblja u ljudskoj povijesti, stoga svaki čovjek iskustveno zna što je kriza. Živi je i identificira kao nešto 
što ga duboko dotiče. Ona je, dakle, egzistencijal čovjekova života ili antropološka konstanta. ${ }^{1}$ Svaka kriza ima utjecaj na osnovnu vrijednost: na ljudski život. „Čovjekova je egzistencija po definiciji krhka. Čovjekov je život gotovo permanentno izložen i ugrožen. Krize svih vrsta mogu nastupiti svakog trenutka, a krizna se stanja održavati dugo. Čovjek ih može i ne biti svjestan, što je zlo za njega. A dok je god u takvu stanju, kako može pokušati izaći iz njega?"“2

Čovjek se uvijek nalazi u opasnosti, i to često onoj smrtnoj od strane procesa koji se događaju u povijesti. ${ }^{3}$ Stoga ne iznenađuje misao Pavla Vuka Pavlovića da je čovječji opstanak s pripadajućim mu svijetom u biti i čudo i tajna. ${ }^{4}$

Kriza je svakodnevna riječ jer je i riječ koja sve i svakoga aficira. Zbog njezine kompleksnosti teško ju je interpretirati i definirati. Definirati krizu značilo bi i omeđiti je, naći modele rješavanja i oduzeti joj moć. Upravo je to i jedan od razloga bavljenja krizama, ne osnaživanje, nego oduzimanje moći krizama.

Etimološki gledano, riječ kriza potječe iz grčkoga jezika od riječi krisis, što znači prijelom, prekretnicu, polazno teško stanje. ${ }^{5}$ Označavala je „presudu” ili „odluku”, to jest presudni trenutak. Kriza je raskorak između onoga „može biti“, ali i ,još nije“ u smislu rješavanja. Drugim riječima, krize postoje kako bismo promislili, procijenili, učinili izbor, odnosno odabrali ono djelovanje koje smatramo najboljim.

Iako je cilj oduzeti joj autoritet i moć, kriza prouzročena virusom COVID-19 imala je apokaliptičan prizvuk. ${ }^{6}$ Kao da je stoljećima prije autor ove misli anticipirao naše doba: „Da se u životu doista odrazuju utjecaji Boga i vraga, ta je Berdjajevova tvrdnja dovoljno utvrđena činjenicama, koje obilježuju suvremeni život. Jer današnja strepnja za

Usp. Ivan Koprek (ur., Kako preživjeti krizu?, Uloga i mjesto poslovne etike u vrijeme krize, Filozofsko-teološki institut Družbe Isusove, Zagreb, 2013., str. 41.

2 Ivan Supučić, „Kriza vrednotâ i kriza kulture“, Bogoslovska smotra, Zagreb, god. LXXI. (2001.) br. 2. - 3., str. 381.

3 Usp. Nikolaj Berdjajev, Sudbina čovjeka u suvremenom svijetu, Verbum, Split, 2007., str. 8.

$4 \quad$ Usp. Franjo Zenko, Novija hrvatska filozofija, Školska knjiga, Zagreb, 1995., str. 445.

5 Usp. I. KopreK, $n$. dj., str. 8.

6 COVID-19 - akutna virusna bolest uzrokovana koronavirusom SARS-CoV-2. 
egzistenciju života, ugroženoga pohlepom i mržnjom i razaranjem usavršene tehnike - nije li zar to demonska tragika čovječanstva?"

Kriza koja nas tako snažno dotiče ima svoje specifičnosti koje se ogledaju u: posvemašnjoj nepoznatosti te sile; nestajanju povlaštenih skupina koje bi bile izuzete iz krize; sveprisutnosti, postala je ono što ne mogu sve krize; nastupila je bez ikakva prethodnog upozorenja; posljedice za budućnost nesagledive su; gotovo do temelja onemogućila je ili razgradila odnose sve do temeljne zajednice, obitelji.

U ovoj krizi nema izuzetih, svi participiramo na jedan način, a to je pozicija potencijalne žrtve. ${ }^{8}$ Upravo zbog pozicije žrtve krizni događaji spadaju u ono što se naziva „vrlo osjetljivim društvenim temama"9. Zbog osjetljivosti tematike postavlja se pitanje kako odgovoriti na ovu krizu i kako vrjednovati odgovor. Jedan od odgovora na krizu nude i mediji jer medijsko izvješćivanje igra ključnu ulogu u percepciji, upravljanju, znanju i rješavanju krize. Kriza nije poseban znak preko kojega bi medijski djelatnici trebali shvatiti na što su pozvani. Na novu situaciju trebaju primijeniti profesionalna načela i vještine.

\section{Pojmovno određenje krize}

Gledano s povijesne ili filozofske perspektive, doživljaj krize bio je usko vezan s physisom, mitološkom ili eshatološkom perspektivom. Iako u sebi nose osobine imaginarnoga, fatalnoga, mističnoga, elitističkoga, autoritarnoga, jedno je sigurno, krize su stvarne. Prvi pristup krizama u prošlosti bio je fatalističko prepuštanje, a potom opiranje posezanjem za magijskim ritualima. Za promjenu percepcije krize bila je potrebna antropologija. „Izvući“ čovjeka iz stanja kaosa značilo je i početi rješavati krizu racionalno, tražiti odgovor i odgovornost za nju. Mišljenjem

F. ZENKo, $n$. $d j$., str. 361 .

$8 \quad$ Usp. „pandemija“, (grč. $\pi \alpha \nu \delta \eta \mu i \alpha$ : sav narod), širenje neke bolesti na velika prostranstva, tj. na više država, cijeli kontinent ili cijeli svijet. Svjetska zdravstvena organizacija proglasila je pandemiju bolesti COVID-19 (2020.). Hrvatska enciklopedija, mrežno izdanje. Leksikografski zavod Miroslav Krleža, <http://www.enciklopedija.hr/Natuknica.aspx?ID=46397>, (19. 1. 2021.).

9 Claude-Jean Bertrand, Deontologija medija, Sveučilišna knjižara, Zagreb, 2007., str. 29. 
se, dakle, utvrđuje da je uglavnom čovjek odgovoran za krize, a ne neke više sile. To dovodi do zaključka da ih čovjek može prevenirati, objasniti, pa i riješiti.

U pokušajima definiranja krize nalazimo i mišljenja da su one po svojoj prirodi kaotični događaji, iz čega zaključujemo da čovjeka vraćaju u ono stanje koje je snagom uma htio prevladati. One su, dakle, bez obzira na to tko im je tvorac ili uzročnik, trajni izazov čovjekovu umu i potencijalima. Čovjek ih snažno osjeća jer dovode u pitanje i demonstriraju propast svega što je smatrao sigurnim i svega što je smatrao da ulazi u isključivo pitanje ljudskih moći i potencijala. Kriza sve dovodi u pitanje, pa i samoga čovjeka, njegov način razumijevanja sebe i svijeta oko sebe. Može se reći da je direktan udar na ciljeve i vrijednosti.

Naš svakodnevni govor impregniran je krizama: vidljivim, latentnim ili potencijalnim. Govor o krizi, subjekti krize kao i krizni potencijal različiti su. Tako se govori o krizi identiteta, kulture, znanosti, ekonomije, okoliša itd. Svaka nova ljudska ili prirodna aktivnost može prouzročiti krizni događaj. Sigurno je da se susret s krizom mora dogoditi, a onda slijede identifikacija pa definiranje. Mišljenje o njoj nije jednoznačno, kao što nisu jednaki ni doživljaji krize. Svaka ima specifičan potencijal, koncentraciju, difuziju, vrijeme i doseg. Obilježava početak i kraj jednoga razdoblja, pa je time i povijesna danost.

U definicijama kriza stavlja se naglasak na neočekivanost i nepredvidivost, nejasnoću uzroka, vremenski pritisak, nesigurnost i posljedice. „Svaka kriza redovito uključuje aspekt nesigurnosti i neodlučnosti. Kriza je, po definiciji, prijelazno stanje ishod kojega je neizvjestan. A to izaziva tjeskobu i potencira samu krizu. Ona postaje objektivni i subjektivni doživljajni problem." ${ }^{\text {10 }}$

Inicijalni opis krize proizlazi iz oslanjanja na njezino medicinsko definiranje, kao što su i odgovornost i povjerenje najprije opisani i zahtijevani u medicinskome kodeksu. Upravo iz medicinskoga načela Nil nocere („ne škoditi“) možemo razumjeti i odgovornost i povjerenje.

1o I. SuPiČIĆ, $n$. dj., str. 383. 
„Svaka je kriza neki izazov. Pred spomenutim zbivanjima ljudi su pozvani 'krinein', osvješćivati se, ulaziti u sebe, suditi, donositi odluke, tražiti protumjere da se bolest prebrodi. To znači da u svakoj krizi progovara onaj skriveni impuls za ozdravljenjem, za zdravim napretkom, za životom. Zapravo, pitanje o čovjeku." ${ }^{11}$

Čovjek je i biće krize, znači li to da se on u njoj konstituira i potvrđuje kao čovjek? Čovjek koji joj se suprotstavlja vrlinama. Trankvil Andreis, problematizirajući o vrlini, argumentirao je da je nužno da jednom bude nagrađena. ${ }^{12}$ Napredovanje u vrlini najteže je u krizama i baš zbog toga zaslužuje da vrline budu istaknute. Seneka je davno napisao da se tvrdnja o veličini čovjeka može potvrditi samo ako mu sudbina dadne priliku da pokaže svoju vrlinu. Vrlina bez protivnika slabi, demonstrira se tek kakvoćom podnošenja nedaća u životu.

Kriza bi bila nevrijedna pozornosti kada ne bi utjecala na vrijednost kakva je, primjerice, ljudski život. Ona je izazov jer ispituje ljudske potencijale, često i u situaciji u kojoj bi trebalo priznati bespomoćnost. „Svi se ljudi nalaze pod znakom brige; sigurnost danas ne znači i sigurnost sutra. ${ }^{\text {13 }}$ Činjenica da na krizu možemo samo djelomično utjecati, a da je njezin ishod teško predvidjeti razlama ljudsku egzistenciju. Međutim, Jonas kaže: „Mišljenje koje još može ugledati šansu, i tako pozvati da se nešto čini, jest zaista isto moćno mišljenje kao ono koje nas je otjeralo u krizu i nemoguću bijedu. Upravo ovo mišljenje mora ostati otvoreno za ovu šansu, ako uopće treba biti nade. No time nisam kazao da se nadam, nego da je moja dužnost ne prepustiti se rezignaciji."14

Kriza je, dakle, nešto prema čemu se treba aktivno postaviti. Uvijek je prati promjena, a svaka promjena u sebi može nositi stvaralačku, inovativnu snagu i otkrivati neiskorištene potencijale. Riječ je o aktivnome i disperzivnome procesu koji se samo aktivnim angažmanom može

$11 \quad$ I. KOPREK, $n$. $d j$., str. 42.

12 Usp. Erna Banić-Pajnić - Mihaela Girardi Karšulin - Marko Josipović, Magnum miraculum - homo, Veliko čudo - čovjek, Hrvatska sveučilišna naklada, Zagreb, 1995., str. 93.

$13 \quad$ N. BERDJAJEV, $n$. dj., str. 59 .

${ }_{14}$ Hans Jonas, Etičkoj se perspektivi mora pridodati nova dimenzija, str. 13O., IVAN KeŠINA: Znanost-vjera-etika, Crkva u svijetu, Split, 2005., str. 251. 
pasivizirati. Kriza s kojom se zajednički suočimo može biti neutralizirana, u protivnome postaje nasilna. Svaka kriza, prema gore navedenomu, nuka čovjeka na aktivaciju svih njegovih kapaciteta. „Kriza je, s jedne strane, neželjeni događaj - jer sadržava prijetnju nečemu postojećemu. No iz krize se može i mora učiti. Prava bi kriza, zapravo, trebala završiti pozitivnim ishodom. Iz nje se može izaći ojačan. Iz nje se mora izaći pametniji." ${ }^{15}$

Neka sila uvijek pokrene krizu, ali kriza rezultira pokretanjem novih snaga i sila. Za razliku od katastrofa kojima se prepuštamo, kriza zahvaća sadašnjost, ali na agendu stavlja i posljedice za budućnost. Novije krize toliko kauzalno dosežu u budućnost kako to do sada nikad nije bivalo. Kada se pojavi, ne možemo djelovati na uzroke, ali možemo na aktivaciju ljudskih potencijala. Nijedna kriza nije identična, svaka je novum, ali i nudi određene nove ravnoteže, pristupe, rješenja i odnose. Kriza je uvijek opasnost da će se nešto što je izgrađeno urušiti, ali Ratzinger nas upozorava da bi opasnost bila kada bismo gledali samo na nju. ${ }^{16}$ Dakle, kriza dovodi u pitanje i vjerodostojnost i reputaciju, kao i održivost, ${ }^{17}$ ali je uvijek katarza i izazov. Za razliku od nekih drugih pojavnosti koje djeluju na čovjeka tako da ga pasiviziraju, ražaloste, učine moralno inferiornim, ona može aktivirati odlučnost, samopotvrđivanje, ozbiljnost, red i poredak, odnosno može biti aktivator čovjekovih potencijala.

Nije cilj u krizi tražiti njezine vrijednosti jer je to besmisleno i niječe samu definiciju krize, ali cilj je u naporima izlaska iz krize prepoznati vrijednosti koje tek tada izgledaju spoznatljive. Samo povjerenje može minimalizirati ili anulirati nesigurnost koju ona proizvede. Nesigurnost postavlja pitanja, traži odgovore, odnosno odgovornost za posljedice. To je i razlog zašto smatramo da je u krizi vrijedno govoriti o povjerenju i odgovornosti. „Bio bi nevriedan bolje budućnosti, tko ne bi na očigled golemih žrtava smatrao sebe suodgovornim za izlaz iz svjetske borbe $u$

$15 \quad$ I. KOPREK, $n$. dj., str. 7

${ }_{16}$ Usp. Božo GolužA, Pouke i misli velikoga Ratzingera, Crkva na kamenu, Mostar, 2019., str. 50 .

17 Usp. Ian I. Mitroff - Paul Shrivastava - Firdaus E. Udwadia, „Effective crisis management", The Academy of Management Executive, god. I. (1987.) br. 3., str. 283. - 292. 
osnovnim pitanjima života. Dati sebi računa u toj odgovornosti, prvotni je zadatak misaona čovjeka..." ${ }^{\prime 18}$

Čovjek se kao biće mogućnosti može prepustiti dominaciji krize ili je preobraziti. Samo čovjek može pitati o onim tzv. „graničnim situacijama“ koje spominje Karl Jaspers i koje je kriza ponovno aktualizirala. Iz susreta sa samim sobom u graničnim situacijama proizlazi i pitanje o slobodi i odgovornosti.

Postoje slobodni i odgovorni čini koje vršim u teškim trenucima svoga života - ponekad suočen sa smrću - ali koji nekako izbijaju iz najdublje nutrine moga „ja“, kakvo je postalo u prošlosti i održava se do danas, do trenutka samoga čina. Moguće ih je izvršiti samo ukoliko ja, koji sam nekoć postao takvim, njim ostajem i do dana današnjega. Iz, u prošlosti rođene i nakupljene, snage, iz vjere koju sam živio, voljenosti od kojih sam živio, iz žudnji koje sam nastojao ostvariti, rađa se moć koja u meni, ako mi izvršenje čina ima uspjeti, mora biti živa. ${ }^{19}$

\section{1. Mediji i krize - uzajamna interpretacija}

I mediji i kriza povezani su sa složenošću ljudske komunikacije i uključuju različite oblike donošenja odluka i sukoba interesa. ${ }^{20} \mathrm{U}$ suvremenome društvu neizbježnost je ono što karakterizira i medije i krizu, no nije jedina poveznica. Poveznice su im čovjekov utjecaj i utjecaj na čovjeka. Baš kao i mediji, i kriza je uvijek akcija koja provocira reakciju. Ona nuka na odgovor i odgovornost, a traženjem odgovora i propitivanjem odgovornosti bave se mediji. I u medijima i u krizi brzina je važan kvalitativ. Brzina kojom krize eskaliraju zahtijeva i jednako brzo medijsko praćenje istih. „Privlačnost“ kriza konstanta je kako za širu javnost tako i za medije. Bilo da se radi o čistoj znatiželji ili javnome interesu, samo je jedan imperativ: brzo informiranje.

\footnotetext{
F. ZENKO, $n . d j .$, str. 374 .

Roman IngARden, Mala knjiga o čovjeku, Breza, Zagreb, 2012., str. 49-50.

2o Usp. MA RINGO: „Media, Crisis, and SARS: An Introduction“, Asian Journal of Communication, god. XV. (2005.) br. 3., str. 242.
} 
Mediji i kriza u simbiotičkome su odnosu. Postoje mišljenja da kriza nastupa tek kada je mediji, državne institucije i utjecajne skupine proglase takvom. ${ }^{21}$ Kada je riječ o velikim krizama, one su snažne, imaju velik utjecaj i sposobnost mijenjati svijet. Medijski odgovor na takvu vrstu izazova mora biti snažan, što medijima predstavlja izazov i daje veliku moć. Mediji su na neki način čimbenik dinamike krize, ali i odnosa u njima. Zahvaljujući njoj, dosežu visinu svoga poslanja. Krizi je potrebna tehnologija medija jer joj upravo to daje vidljivost.

Ona u sebi sadrži sve parametre vijesti, pa je ona uvijek i vijest. Za razliku od mnoštva dnevnih vijesti koje često ne iziskuju nikakvu reakciju od korisnika, osim da budu apsorbirane, vijesti o krizama uvijek imaju praktičnu uporabnu vrijednost. Ozbiljne krize same se nameću jer je riječ o iznenadnome, neočekivanome i drugačijem. U slučaju krize mediji više ne određuju vrijeme kada će se plasirati neka poruka, nego kriza sama sebi određuje relevantnost. Odgovor na često postavljano pitanje o tome tko određuje sadržaj u medijima za vrijeme kriza pojednostavljen je: sama kriza.

Informacija o krizi nije dovoljna. Potrebni su njezina medijska interpretacija te suočavanje s njom. Bitan je način na koji se izvješćuje, analizira i interpretira. Komunikacija u vrijeme krize treba biti dijelom njezina rješenja, a ne produbljivanja. Krize iziskuju novu medijsku strategiju. To je strategija budne, aktivne i informirane javnosti. ${ }^{22}$ Javnost odnosno građani moraju biti aktivni čimbenici. Uloga medija iznimno je važna u vremenima kriza jer kvaliteta života građana ovisi i o njihovu izvještavanju. Tijekom krize mediji više nisu supstitut, nego refleksija onoga što proživljavamo. Postaju naša jedina aktivnost, a u krizama većih razmjera i jedina veza sa svijetom.

Iako je danas tražena i „raširena literatura apsurda ${ }^{\text {“23 }}$, uočavamo da je potreba za kvalitetnim medijima najizraženija u vremenu krize. Mnogi teoretičari krize kažu da je ona prilika. Postavlja se pitanje: „Kako krizu

${ }^{21}$ Usp. Božıdar NovaK, Krizno komuniciranje i upravljanje opasnostima, Binoza press, Zagreb, 2001., str. 28

22 Usp. Ante Gavranović, Poslovno novinarstvo izmedu etike i zarade, Dnevnik, Zagreb, 2011., str. 99.

$23 \quad$ B. GolužA:, $n$. dj., str. 53 . 
pretvoriti u šansu?" Tomić smatra da su iskrenost i poštenje odnos koji krizu kao opasnost može pretvoriti u krizu kao šansu. ${ }^{24}$

Ideje o poštenju izaziva simpatije prema novinarima koji se trude na najbolji mogući način kako bi točno izvješćivali u vrlo teškim okolnostima. Izvješćivanje nije lagan posao, a poštenje više ukazuje na dobre namjere novinara negoli objektivnost. Publika očekuje da će vijesti biti istinite i uvjerljive, pa je poštenje novinara kategorija kojoj se može više vjerovati negoli objektivnosti, misli Bennett. ...Poštenom novinaru vjerujemo čak i kad racionalizira informaciju jer se nadamo kako ju je prikazao na najbolji mogući način. ${ }^{25}$

Kriza je prelazak iz staroga, poznatoga načina komunikacije u novi. Taj novum još nije nešto posve novo, nego pronalaženje novoga uz pomoć staroga, uz pomoć prošlih formi i uzusa. Koprek smatra da se kroz krize društvo brine o svojim postavkama i, čisteći se od pogrešnoga, raste, napreduje. ${ }^{26}$ Svaka kriza vodi do ponovnoga preslagivanja, prepravljanja, promišljanja, ona je izazov čovjekovoj inteligenciji. Tako, primjerice, $u$ novinarstvu vodi prema onomu što se smatralo arhaičnim: istinitosti, profesionalizmu, odgovornosti, poštenju, povjerenju itd. Ovi pojmovi, prvenstveno odgovornost i povjerenje, ne predstavljaju anakronizam suvremenoga društva, već sine qua non pretpostavku bez koje se ne može zamisliti uspješno funkcioniranje nijedne profesije ni društva u cjelini.

\section{Odgovornost - imperativ u krizi}

Roman Ingarden smatra da se jedino čovjek osjeća odgovornim za svoj način života, osobito onda kada mu ne uspije ostvariti vrijednosti koje su neophodne za njegovo unutarnje dostojanstvo. ${ }^{27}$ Hans Jonas smatra je čovjekova moć korijen potrebe odgovornosti i ono što je dovodi u središte morala. Odgovornost se nalaže i očekuje zbog činjenice

\footnotetext{
24 Usp. Zoran Tomić, PR blog, Synopsis, Zagreb-Sarajevo, 2009. str. 112.

25 Stjepan Malović, Mediji i društvo, Sveučilišna knjižara, Zagreb, 2007., str. 10.

${ }_{26}$ Usp. I. KOPREK, $n$. $d j$., str. 7 .

27 Usp. Roman Ingarden, Mala knjiga o čovjeku, Breza, Zagreb, 2012., str 17.
} 
da nema kraja, njezin je doseg dalekosežan, a upravo je moć ono što povezuje htijenje i trebanje. ${ }^{28}$

S filozofske točke gledišta polazi se od pretpostavke da su mediji predstavnici javnosti, ali uz odgovornost. Novinarstvo koje je svrha samomu sebi i izuzeto iz društva posve je nezamislivo te gubi svoju primarnu funkciju. Mediji su dio društva i kao takvi moraju ispunjavati važnu funkciju informiranja javnosti koja nikako ne bi smjela izostaviti odgovornost.

Potrebno je razlikovati četiri različite situacije u kojima se javlja fenomen odgovornosti:

1) Netko snosi odgovornost za nešto ili, drugim riječima, za nešto jest odgovornost.

2) Netko preuzima odgovornost za nešto.

3) Neko je za nešto pozvan na odgovornost.

4) Netko djeluje odgovorno. ${ }^{29}$

Društvo ima određena očekivanja od medija koja se ne odnose samo na distribuciju informacija, nego na informacije koje će biti istinite i imati uporabljivu vrijednost. Bertrand ističe da poboljšanje medija nije samo poželjna promjena, nego da o njemu ovisi sudbina čovječanstva. ${ }^{30}$ Odgovornost kao postulat u medijima stoji u proturječju prema sebičnim medijskim interesima.

Izvještavanje u krizama velik je etički i profesionalni izazov te, posljedično, velika odgovornost. Autori Harold Lasswell i Charles Whright u funkcije medija ubrajaju: nadzor, korelaciju, prijenos društvenoga nasljeđa i zabavu. Pod funkcijom nadzora smatraju da je uloga medija upozoravati primatelje na opasnosti te ih informirati o važnim životnim temama. ${ }^{31}$ Smatra se da se u vremenu krize, uz temeljne funkcije:

${ }_{28}$ Usp. Hans Jonas, Princip odgovornosti: pokušaj jedne etike za tehnološku civilizaciju, Veselin Masleša, Sarajevo, 1990., str. 183. - 184.

$29 \quad$ Usp. R. INGARDEN, $n$. dj., str 57.

3o Usp. C-J. Bertrand, $n$. dj., str. 8.

31 Usp. Werner J. Severin - James W. Tankard, Communication theories, Longman, New York, 2001., str. 321. -323 . 
poučiti, informirati, zabaviti, na ljestvici potrebnih posebno ističe i gore definirana funkcija nadzora. Tijekom krize ovakvih razmjera iznimno su važni informiranje i gotovo zaboravljena funkcija medija, a to je obrazovanje ili edukacija. Mediji svjesni odgovornosti za sve sastavnice ljudskoga života u vremenu krize koncipiraju svoj program tako da korisnicima pružaju relevantne i potkrijepljene informacije, educiraju ih o problemima, ali ne zanemaruju zabavni dio koji se pokazuje i nužnim segmentom za psihičko zdravlje građana. Pri tome treba paziti da se ne podrede opasnoj simplifikaciji sadržaja ili redukcionizmu. Trebali bi postupati po načelu koje je Einstain istaknuo za znanost: učiniti sve što je moguće jednostavnijim, ali ne jednostavnijim od toga..$^{32}$

Weber smatra da je novinarstvo visoko odgovoran poziv, gotovo jednak pozivu znanstvenika, jer po prirodi stvari upravo neodgovorna novinarska djelatnost ostaje u sjećanju zbog svoga užasnog učinka. Wilkins smatra da novinari, komunicirajući putem vijesti, imaju isti set etičkih obveza kao i znanstvenici ili zdravstveni radnici. Njihov je zajednički cilj spasiti živote i ublažiti ljudski utjecaj bolesti. Zdravstvene krize potiču novinare da promijene svoju ulogu iz normalna kritičnog izvještavanja u izvještavanje o vijestima kojima je cilj spasiti život. Međutim, nakon što prođe neposredna kriza, uloge novinara vraćaju se u uloge društvenih nadzornika. ${ }^{33}$

Ponekad se čini da mediji zapravo iščekuju krize jer tragaju za onim što je nesvakidašnje, onim što izaziva strah, nepoznanice, dileme, neizvjesnost, borbu, razaranje, stradanja i žrtve. Uočava se da su ovakve teme medijski poželjne, ali izvještavanje o njima mora biti odgovorno.

Medijska je odgovornost učiniti krizu vidljivom i operabilnom. U ovome slučaju to bi značilo i odaslati poruke koje mogu izazvati promjenu ponašanja, ali i unaprijediti dijalog i suradnju. Takva se odgovornost odnosi na uočavanje odstupanja, ukazivanje na anomalije, osposobljavanje društva na prihvaćanje promjena i prihvaćanje rizika. Bitna razina odgovornosti ogleda se i u širenju horizonata i usmjeravanju pozornosti.

32 Usp. Ivan ČEHOK - IvAn Koprek, Etika - priručnik jedne discipline, Školska knjiga, Zagreb, 1996., str. 136.

$33 \quad$ Usp. M. RINGO, $n$. $d j$., str. 241. -246. 
Mediji su učinili vidljivim ljudske napore u borbi protiv pandemije i naglasili načelo suodgovornosti za (ne)uspjeh.

Profesionalizam je jamstvo da će odgovornost biti pratitelj medijske slobode. Izvještavanje u krizama i ugrozama iz neznanja i nepripremljenosti može donijeti ogromnu štetu. Potrebno je postaviti pitanja tko i na koji način treba izvještavati o takvim događajima, a pri tome se ne misli na zagovaranje bilo kakve diskriminacije ili cenzure, nego na propagiranje što profesionalnijega pristupa.

„Netko može intelektualno biti potpuno svjestan što je prava stvar, ali jedino ljudi s 'karakterom' su u stanju ono što je pravo u otežanim okolnostima ili čak u izazovnim okolnostima provesti u djelo. “ ${ }^{34} \mathrm{U}$ vremenu krize angažiraju se novinari koji imaju znanje i visoka moralna načela. Ne začuđuje takav izbor ako imamo u vidu da je i koncept odgovornosti dobio svoj zamah kada je novinarstvo počelo privlačiti obrazovane ljude koji su uspostavili etičke standarde u ovome području i nastojali ih ispoštovati.

Medijsko vrijeme ne mjeri se standardnim vremenskim mjerama, ono je u novome dobu civilizacije mjerljivo od krize do krize, od preokreta do preokreta. Mediji mogu spašavati živote objavljujući korisne informacije te održavanjem stalnoga interesa ljudi koji je ključan za animiranje građana na suradnju i pomoć. Zbog toga je na društvenu odgovornost medijima potrebno primijeniti „historijski imperativ“ Maxa Mullera: „Čini to što nitko drugi ne može činiti i što možeš u zajednici preuzeti kao upravo svoju jedinu sadašnju zadaću!“

„Dobrobit, interes, sudbina drugih je, zbog okolnosti ili sporazuma, došla u moje ruke, a to znači da moja kontrola nad njima istovremeno uključuje moju obavezu za njih. Vršenje moći bez vođenja računa o obavezi onda je 'neodgovorno', to znači: dolazi do raskida povjerenog odnosa odgovornosti.“" 35

Neodgovorno ponašanje medija odnosi se na: ugrožavanje prava na privatnost, ometanje rada službi, ometanja istraga i potraga,

34 Francis Fukuyama, Povjerenje: Društvene vrline $i$ stvaranje blagostanja, Izvori, Zagreb, 2000., str. 52.

35 H. JoNAS, $n$. $d j$., str. 135 . 
populariziranje zločina ili zločinaca, širenje panike. Potrebno je voditi brigu o sadržajima koji se trebaju objavljivati u svezi s događajem, a da se pri tome ne čini dodatna šteta. U ovoj bi krizi primjeri neodgovorna izvještavanja bili zazivanje apokalipse te stereotipno prikazivanje oboljelih i najugroženijih kategorija pučanstva.

Virus COVID-19 „zarazio je“ i medije, ali je većina njih djelovala odgovorno. Krizi su oduzeli apokaliptičnost, okus katastrofe koja baca u nemoć, a isticali su čovjekovu moć da bude odgovorno biće. Ljudsko ponašanje mjerilo se mjerama odgovornosti. Novinari su bili dio priče, nije bilo imunih, svi su bili u jednakoj mjeri ranjivi i potencijalno ugroženi. Nisu izvještavali kao da su izvan priče, osjećala se duboka involviranost u svaki podatak i odgovorno postupanje bez stereotipiziranja, traženja krivca, prozivanja, širenja panike i sijanja straha. Pred novinarima i urednicima bio je mučan zadatak kako napisati točna i razumljiva izvješća, a pri tome izbjeći širenje straha i panike. Novinari su bili i skupina koja je osjećala ugroze s više strana, od opasnosti od zaraze pa do opasnosti od gubitka posla, zbog čega im je bilo teže očuvati emotivnu udaljenost koja se očekuje od profesionalaca. Prema mišljenju Christophera Dunkleyja, pobornika faktografskoga pristupa, udaljenost predstavlja osnovni element bez kojega je nemoguć profesionalni odnos u radu, što je posebno važno u kriznim situacijama. Dunkley, kritizirajući empatičku teoriju, piše: „Novinari počinju vjerovati da ono o čemu izvještavaju treba odražavati njihov emotivni doživljaj. Odatle do selektivnosti i manipulacija činjenicama u korist jedne strane samo je korak, i to možda čak nesvjestan. ${ }^{{ }^{36}}$ Novinari su uglavnom profesionalno postupali, iako su mediji bili taoci drame nad kojom nisu imali kontrolu. ${ }^{37}$

I u medijima se odražavao pojam straha koji spada pod pojam odgovornosti, a to je ono što Jonas naziva strahom za predmet odgovornosti. On zaključuje da je odgovornost kao obveza priznata briga za neki drugi bitak, koja, uz svijest o ugroženosti njegove povrjedivosti, postaje

36 Christoper Dunkley, „Whose News is It Anyway?“, Finacial Times, 22. IX. 1997., str. 11., prema Vladimir BAROVIĆ, „Objektivnost, novinarska etika i izvještavanje u kriznim situacijama“, Medijske studije, Zagreb, god. II. (2011.) br. 3. - 4., str. 118. - 126.

37 Usp. Sherry RicChIARDI, „The Anthrax Enigma“, American Journalism Review, god. XXIII. (2001.) br. 10., str. 18. 
„zabrinutost“. Međutim, strah kao potencijal imamo već u onome prvotnom pitanju koje je začetak svake aktivne odgovornosti: „Što će mu se dogoditi ako ga se ja ne prihvatim?" Što je odgovor nejasniji, jasnije se ocrtava odgovornost. ${ }^{38} \mathrm{U}$ ovome vidu odgovornosti nailazimo i na ranjivost, a ranjivost je karakteristična i za povjerenje.

\section{Povjerenje kao katalizator opasnosti}

Povjerenje je pratitelj i posljedica odgovorna djelovanja, ali je njegovo uspostavljanje i prvi cilj u bilo kojoj komunikaciji. ${ }^{39}$ Ovaj je zahtjev posebno nužan u vrijeme krize. Puko informiranje ne može biti preduvjet stvaranja povjerenja. „Povjerenje se ne nalazi u integriranim čipovima ili kablovima od optičkih vlakana. Iako uključuje izmjenu informacija, povjerenje se ne može svesti na puku informaciju. “40 Mogli bismo reći da je povjerenje jedan od katalizatora opasnosti koja se nalazi u neravnoteži između prijetnji koje su se nadvile nad svijet i moralna odgovora. Povjerenje pretpostavlja prisutnost rizika, ali i to da postoji alternativa. ${ }^{41}$

Ako nismo sigurni u vrijednost povjerenja, dovoljno je pokušati zamisliti svijet bez njega. Taj svijet ne bi bio po mjeri čovjeka jer je nepovjerenje, kako navodi Thomas Hobbes, jedan od načelnih uzroka sukoba. ${ }^{42}$ Joseph je Ratzinger smatrao da ljudski život postaje nemoguć kada se nema povjerenja u drugoga i druge, a ni društvo ne može živjeti bez njega. ${ }^{43}$

Povjerenje je i predmet istraživanja raznih znanstvenih disciplina. Nije ga lako definirati ni objasniti zato što postoje različiti tipovi. Od antičkih vremena postoji zahtjev za harmonijom u ljudskome životu, a upravo se na povjerenju temelje harmonični odnosi. Dakle, inicijalno u definiranju počinjemo od očekivanja neke harmonije i uspostave

\footnotetext{
${ }_{38}$ Usp. H. Jonas, $n$. dj., str. 312.

39 Usp. Z. Tomić, $n$. dj., str. 68.

4 F. Fukuyama, $n$. $d j$., str. 39.

${ }^{41}$ Usp. Sirkka L. JarvenpaA - Dorothy E.leidner, „Communication and Trust“, Organization science, god. X. (1999.) br. 6., str. 811.

42 Usp. Thомаs Новвеs, Levijatan, Naklada Jesenski i Turk, Zagreb, 2004., XIII., 6.

$43 \quad$ Usp. B. Goluža, n. dj., str. 67.
} 
odnosa. Povjerenje uvijek ima u vidu drugoga kao i očekivanja. Pri tome se polazi od očekivanja da se radi o istinitoj, točnoj, objektivnoj, poštenoj, pouzdanoj i kompletnoj informaciji. Takva očekivanja može ispuniti samo onaj komunikator koji pokazuje kompetentnost. Riječ je, dakle, o neprekidnome procesu jer takvo očekivanje komunikator ima i od svojih izvora. Nema povjerenja bez uključenosti svih aktera pa ga na neki način možemo shvatiti kao dijalog društva.

Povjerenje je očekivanje pojedinca da se može osloniti na riječ, obećanje, usmenu ili pisanu tvrdnju drugoga pojedinca ili skupine. ${ }^{44} \mathrm{Iz}$ danoga se može zaključiti da je važno uvjeravanje koje je utemeljeno na racionalnim argumentima i poštovanju drugoga. U ostvarivanju povjerenja važno mjesto zauzima i briga jer u davanju povjerenja čovjek se izlaže ranjivosti i prihvaća je. Ako se kriza i ranjivost uzmu u obzir, čini se utemeljenim izabrati povjerenje. „Kad smo nesretni, treba učiniti samo jedno, jedno i to je sve. Treba imati povjerenja.“" 45 Posljedično se rađa i očekivanje da je onaj kojemu se vjeruje u potpunosti posvećen povjerenoj obvezi. Neki su teoretičari mišljenja da povjerenje uključuje dodir. ${ }^{46}$ Upravo su moderne tehnologije dokazale da se povjerenje ne mora temeljiti na fizičkoj bliskosti, ali mora biti u skladu s pet središnjih načela:

- kompetencija: trebate biti u stanju izvršiti ono što kažete

- pouzdanost: trebate izvršiti svoja obećanja i uraditi ono što kažete

- iskrenost: treba postojati transparentnost u vašim poslovima

- jednakost: osjećaj pravednosti između strana

- davanje: ako nešto dajete, pokazujete predanost odnosu. ${ }^{47}$

Osvjedočeno govorenje istine temelj je povjerenja, odstupanje od istine ili odstupanje od traženja istine najeklatantniji je primjer nebrige za povjerenje. Upravo ta ukorijenjenost $u$ istinu daje povjerenju dimenziju

${ }_{44}$ Usp. Julian B. Rotter, „Interpersonal trust, trustworthiness, and gullibility“, American Psychologist, god. XXXV., 1980., str. 1.

45 Veroniqu Eolmi, Bakhita, Verbum, Split, 2020., str. 295.

46 Usp. S. L. JARVENPAA - D. E. LeIDNER, $n$. dj., str. 791.

$47 \quad$ Usp. Z. Tomić, $n$. dj., str. 68. 
dobrovoljna čina. Ono samo po sebi nema nasilnu komponentu jer se nikoga ne može prisiliti na davanje povjerenja. Dragovoljan akt nastaje u uvjetima za koje čovjek procjenjuje da odgovaraju poštovanju ljudskoga dostojanstva i zauzimanju za vrijednosti koje su zajedničke. U takvim se uvjetima razvija povjerenje.

Jedna od definicija kaže da je društveno povjerenje „očekivanje koje se javlja u okviru zajednice u kojoj prevladava uobičajeno pošteno i kooperativno ponašanje, zasnovano na pravilima i normama koje su odredili i usvojili članovi te zajednice ${ }^{\text {"48 }}$. Posljednjih desetljeća povjerenje postaje pojam koji svi žele inkorporirati u svoje odnose, privatne i poslovne, jer jača odgovornost i radnu etiku.

Povjerenje je dinamičan proces jer ga je potrebno stjecati, potvrđivati i održavati. Nije svrha samomu sebi, nije nikad jednostran akt nego ukazuje na davanje prednosti poštenju, dijalogu, sudjelovanju, transparentnosti. Iz suočavanja s vlastitim neznanjem ili nemoći javlja se potreba za drugim. Taj je drugi uvijek i drugačiji od nas jer ga percipiramo kao nekoga tko umije i može. Važnost povjerenja raste usporedno sa specijalizacijom u društvu. Specijalizacija je prirodan tijek u postizanju znanja, a jasno je da svatko nema iste mogućnosti i sklonosti. Zbog toga je svaka specijalizacija izrasla kao reakcija na potrebe drugih. Međusobna ovisnost nuka na traženje i zadržavanje pažnje i kontakata. Ovisnost o drugome za ciljeve koji su nam važni implicira moguću ranjivost.

Iznimno je važno kako javnost u kontekstu povjerenja doživlja novinare i medije. Novinari su u ovoj krizi uspjeli zaustaviti i eroziju povjerenja u medije. Primijenili su neka komunikacijska ponašanja koja povećavaju povjerenje: preuzimanje inicijative, komuniciranje entuzijazma, davanje bitna i pravovremena odgovora. ${ }^{49} \mathrm{U}$ svijetu medija povjerenje se temelji na traganju za istinom, odgovornosti, poštenju, objektivnosti, pouzdanosti, preciznosti. Negativna djelovanja koja izravno utječu na rušenje povjerenja jesu sklonost izvrtanju činjenica, trivijalnost

\footnotetext{
48 F. FuKUYAMA, $n$. dj., str. 40.

49 Usp. S. L. JarvenpaA - D. E. Leidner, $n$. $d j$., str. 807.
} 
sadržaja, pristranost, senzacionalizam, neuravnoteženi prikaz. Povjerenje narušava nepravedna, neredovita i nepredvidiva komunikacija. ${ }^{50}$

Društvene okolnosti i kontekst utječu na percepciju i važnost povjerenja. Ono u krizama postaje najvažniji čimbenik jer je aktivator potencijala i rješenje za sadašnjost, odnosno smanjuje nepotrebne pritiske, a one nužne svodi na pravu mjeru.

Javnost je već odavno pravo da zna proširila na pravo da sudjeluje i odlučuje. Medijska komunikacija zahtijeva dijalog jer bez njega ne ispunjava svoju svrhu. U nesrećama ili kriznim situacijama uočavaju se pouzdanje u vlastito rasuđivanje i panika, što se može tumačiti nedostatkom povjerenja, slabom ili gotovo nikakvom edukacijom.

Edukacija je proces koji bi se trebao odvijati prije nego što nastupi neka ugroza, a informiranje se pojavljuje u samome tijeku događanja slučajne situacije. Neke krize nastupe iznenadno i imaju elemente potpunih nepoznanica. U tome se slučaju paralelno s procesom informiranja odvija i edukacija. U slučajevima kada je krizna situacija nepoznanica povjerenje je jedina nosiva konstrukcija dijaloga i uspješne komunikacije.

Povjerenje rijetko postaje vijest, dok nepovjerenje uvijek pretendira tomu jer se negativni elementi lakše primjećuju. Medijska su izvješća orijentir i korektiv u odlučivanju o davanju povjerenja, ali su ujedno i podložni kontroli povjerenja koje im daje publika. ${ }^{51} \mathrm{U}$ oba slučaja procjena ide od istinitosti informacija, dinamike informiranja, transparentnosti i vjerodostojnosti. Mediji su informatori o krizi, njezini tumači, ocjenjivači, ali i dio procesa njezina završetka.

Ne uči se samo o krizama, nego se uči i iz kriza. Mediji svaku krizu moraju vidjeti kao mogućnost jer je jedan od njihovih postulata traganje za neobičnim, iznenađujućim, a krize to svakako jesu. O vrsti i politici

Usp. S. L. JARVENPAA - D. E. LeIDNER, $n$. dj., str. 808

${ }^{51}$ Baloban, Črpić i Ježovita u knjizi Vrednote u Hrvatskoj od 1999. do 2018. navode: „U Republici Hrvatskoj tek 10\% ljudi ima povjerenje u tisak." Također navode da žene više vjeruju tisku od muškaraca (10,9\% naprema 9,9\%), a najvišepovjerenja u tisak imaju stariji od 71 godine života. Vidi više u: Josip Baloban - Gordan Črpić - Josip Ježovita, Vrednote u Hrvatskoj od 1999. do 2018., prema: European Values Study, Kršćanska sadašnjost, Zagreb, 2019. 
medija ovisi hoće li joj oduzeti ili pridodati dramatičnost. Svođenje krize na „pravu mjeru“ zadatak je iskusnih profesionalaca koji takvim proaktivnim, entuzijastičnim i profesionalnim pristupom zavrjeđuju povjerenje. „U određenom smislu, kriza je kompliment čovječanstvu. Ona nam govori: možeš i trebaš bolje. Stvoren si za više. Na svoj obrnuti kadšto bolan, paradoksalan način, kriza je donosilac radosne vijesti o čovjeku." ${ }^{52}$

Ako nema povjerenja, jasno je da svi odnosi postaju otežani ili nemogući, moraju se redefinirati, mora se promijeniti hijerarhija i moraju se uvesti novi akteri. Čak i mediji, kojima je profit primarni motivator u radu, moraju voditi računa o povjerenju kao o krhkoj dragocjenosti. U poslovnim odnosima povjerenje ima pragmatičnu vrijednost, a Fukuyama smatra da ima ogromnu i mjerljivu ekonomsku vrijednost. ${ }^{53}$

Prevladati krizu jedan je od osnovnih imperativa čovjekove egzistencije. Ivan Koprek anticipirao je današnju krizu jer je ustvrdio da je „svaka kriza neki izazov. Pred spomenutim zbivanjima ljudi su pozvani 'krinein', osvješćivati se, ulaziti u sebe, suditi, donositi odluke, tražiti protumjere da se bolest prebrodi. To znači da u svakoj krizi progovara onaj skriveni impuls za ozdravljenjem, za zdravim napretkom, za životom. Zapravo, pitanje o čovjeku“" ${ }^{44}$

\section{Zaključak}

Kriza je sila, ali tom silom treba mudro zagospodariti. Na tome počiva svako zrelo ljudsko djelovanje, pa tako i profesionalno medijsko djelovanje. Znanstvena zajednica pokušavala je demistificirati i objasniti pandemiju izazvanu virusom COVID-19, a njezini bi pokušaji ostali neprepoznati bez medija. Znanstvenoj perspektivi morala se pridodati još jedna, a to je ona medijska, da bi se kriza demistificirala te da bi se izbjegli fatalizam i pesimizam. Radilo se o velikome izazovu u kojemu su se novinari našli pred stvarnošću koja je ponekad nadilazila i njihove

\footnotetext{
I. Koprek, $n . d j$., str. 10.

3 Usp. F. Fukuyama, $n . d j$., str. 22.

$54 \quad$ I. KOPREK, $n$. $d j$., str. 42.
} 
mogućnosti. No, ustrajali su u odgovornosti, pa čak i otišli jedan korak dalje, u smjeru etike brige. U brizi za drugoga mediji su pokazali iznimnu kreativnost i inventivnost. Briga se ogledala i kroz izlaženje iz zone medijskoga komfora i otvaranje tema o pitanjima o kojima se malo znalo. Svaka je osoba kroz medijska izvješća u krizi mogla doživjeti ohrabrivanje, poštovanje, prepoznati vlastitu sliku i dobiti kompenzaciju za prekinute odnose.

Kriza je pokazala da je najučinkovitije sredstvo za djelovanje medija, osim traganja za istinom, demonstriranje odgovornosti ljudima i učvršćivanje povjerenje. Slobodni mediji, ako hoće - mogu, zar to nije iskaz koji govori o odgovornosti i povjerenju? U „novome svijetu“ smanjenih mogućnosti i povećane osamljenosti mediji su nerijetko predstavljali jedinu relaciju. Takvo instaliranje medija ukazuje na važnost povjerenja. Pred njima je bio jedan imperativ: djelovati tako da ne narušavaju slobodu i dostojanstvo ljudi pogođenih krizom, a istodobno apelirati na odgovornost.

U ovoj novoj vrsti komunikacije iščezli su neki komunikacijski uzusi, drugi su se pojavili u promijenjenoj verziji, a neki su pronašli svoju novu dimenziju. Kriza je značila prelazak iz poznatih komunikacijskih tema i obrazaca u nove, ali je potvrdila da načela, koja su smatrana arhaičnima, jedina imaju mogućnost svođenja krize na pravu mjeru.

Mediji su preživjeli krizu uz puno profesionalne borbe, ali i funkcijama informiranja, nadzora, edukacije i zabave pomogli svojim primateljima da prebrode krizno razdoblje. Učinili su vidljivim ne samo krizu nego i ljudske mogućnosti i napore u borbi protiv pandemije. Shvativši odgovornost kao svoju jedinu zadaću u danome trenutku naglasili su povezanost društva i načelo suodgovornosti za (ne)uspjeh. Zauzimanjem za društvo i zajedničke vrijednosti, nastojanjem oko istinitosti, očuvanjem ljudskoga dostojanstva, komuniciranjem entuzijazma mediji su gradili povjerenje usprkos opasnosti. Povjerenje je sila za suočavanje sa svakodnevnicom i pokazatelj odnosa temeljenih na odgovornosti. 


\section{Literatura}

- Baloban, Josip - Črpić, Gordan - Ježovita, Josip, Vrednote u Hrvatskoj od 1999. do 2018., prema: European Values Study, Kršćanska sadašnjost, Zagreb, 2019.

- Banić-Pajnić, Erna - Girardi Karšulin, Mihaela - Josipović, Marko, Magnum miraculum - homo, Veliko čudo - čovjek, Hrvatska sveučilišna naklada, Zagreb, 1995.

- BAROvić, Vladimir, „Objektivnost, novinarska etika i izvještavanje u kriznim situacijama", Medijske studije, Zagreb, god. II. (2011.) br. 3. -4 , str. $118 .-126$.

- Berdjajev, Nikolaj, Sudbina čovjeka u suvremenom svijetu, Verbum, Split, 2007.

- Bertrand, Claude-Jean, Deontologija medija, Sveučilišna knjižara, Zagreb, 2007.

- ČEHOK, IVAN - Koprek, Ivan, Etika - priručnik jedne discipline, Školska knjiga, Zagreb, 1996.

- Fukuyama, Francis, Povjerenje: Društvene vrline i stvaranje blagostanja, Izvori, Zagreb, 2000.

- Gavranović, Ante, Poslovno novinarstvo izmedu etike i zarade, Dnevnik, Zagreb, 2011.

- GolužA, Božo, Pouke i misli velikoga Ratzingera, Crkva na kamenu, Mostar, 2019.

- Hobbes, Thomas, Levijatan, Naklada Jesenski i Turk, Zagreb, 2004.

- Ingarden, Roman,Mala knjiga o čovjeku, Breza, Zagreb, 2012.

- JarvenpaA, Sirkka L. - Leidner, Dorothy E., „Communication and Trust" Organization science, god. X. (1999.) br. 6., str. 791. -815 .

- Jonas, Hans, Princip odgovornosti: pokušaj jedne etike za tehnološku civilizaciju, Veselin Masleša, Sarajevo, 1990.

- KeŠIna, Ivan, Znanost-vjera-etika, Crkva u svijetu, Split, 2005. 
- Koprek, Ivan (ur.), Kako preživjeti krizu?, Uloga i mjesto poslovne etike u vrijeme krize, Filozofsko-teološki institut Družbe Isusove, Zagreb, 2013.

- Malović, Stjepan, Mediji $i$ društvo, Sveučilišna knjižara, Zagreb, 2007.

- Mitroff, I. Ian - Shrivastava, Paul - Udwadia, E. Firdaus, "Effective crisis management", The Academy of Management Executive, god. I. (1987.) br. 3., str. 283. - 292.

- NovaK, BožIdar, Krizno komuniciranje i upravljanje opasnostima, Binoza press, Zagreb, 2001.

- Olmi, Veronique, Bakhita, Verbum, Split, 2020.

- Ricchiardi, Sherry: „The Anthrax Enigma“, American Journalism Review, god. XXIII. (2001.) br. 10.

- Ringo, MA, „Media, Crisis, and SARS: An Introduction“, Asian Journal of Communication, god. XV. (2005.) br. 3., str. 241. - 246.

- Rotter, B. JUlian: „Interpersonal trust, trustworthiness, and gullibility", American Psychologist, god. XXXV., 1980., str. 1. - 7 .

- Severin, W. James - Tankard, J. Werner, Communication theories, Longman, New York, 2001.

- Supučić, Ivan, „Kriza vrednotâ i kriza kulture“, Bogoslovska smotra, Zagreb, god. LXXI. (2001.) br. 2. - 3., str. 381. - 399.

- Tomić, Zoran, PR blog, Synopsis, Zagreb - Sarajevo, 2009.

- Zenko, Franjo, Novija hrvatska filozofija, Školska knjiga, Zagreb, 1995 . 
Original scientific article

Received on November 14, 2020

Accepted on April 20, 2021

IVANa Primorac Bilaver

University of Mostar, Faculty of Humanities and Social Sciences

\section{RESPONSIBILITY AND TRUST IN THE MEDIA CRISIS COMMUNICATION}

\section{Abstract}

In 2020 the World Health Organization declared the global pandemic and thus the greatest crisis in the last decades. Crisis is, first of all, danger, risk, and then opportunity. Every crisis is a permanent challenge for human intelligence and existence, and therefore anthropological constant. A question about crisis is also a question about a human. Crisis is also the media constant and source of the permanent media interest. There is no unique view of defining crisis. From crisis definitions we point out: lack of planning, undesirability, searching for answers and vulnerability. The two latter terms also contain the opportunity for successful media crisis communication. There arises a question: "Can media change crisis and neutralize its possible harmful effects through the concepts of responsibility and trust?" From the ethical point of view crisis invites us to think intensively about the human that media bring us closer in the time of social distance.

Keywords: crisis; human; media; responsibility; trust 